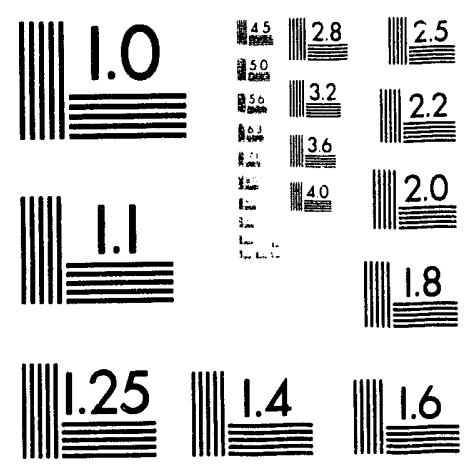



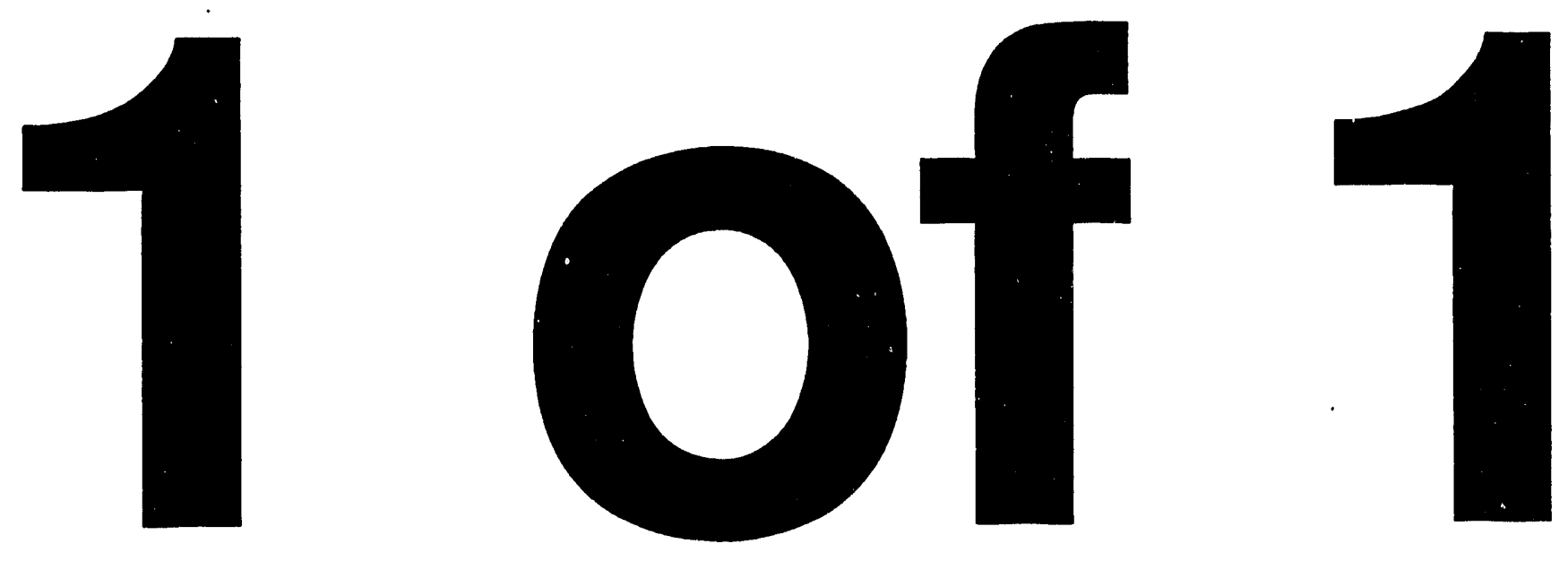


\title{
ENERGY AND CRUDE OIL INIPUT REQUIREMENTS FOR THE PRODUCTION OF REFORMULATED GASOLINES
}

\author{
Margaret Singh \\ Argonne National Laboratory \\ Washington, D.C. \\ Barry McNutt \\ U.S. Department of Energy \\ Washington, D.C
}

The energy and crude oil requirements for the production of reformulated gasolines (RFG) are estimated. Both the energy and crude oil embodied in the final product and the process energy required to manufacture the RFG and its components are included. 'The effects on energy and crude oil use of using various oxygenates to meet the minimum oxygen content level required by the Clean Air Act Amendments are evaluated. The analysis illustrates that production of RFG requires more total energy than that of conventional gasoline but uses less crude oil. The energy and crude oil use requirements of the different RFGs vary considerably. For the same emissions performance level, RFG with ethanol requires substantially more total energy and crude oil than RFG with MTBE or ETBE. A specific proposal by the EPA designed to allow the use of ethanol in RFG would increase the total energy required to produce RFG by $2 \%$ and the total crude oil required by 2.0 to $2.5 \%$ over that for the base RFG with MTBE.

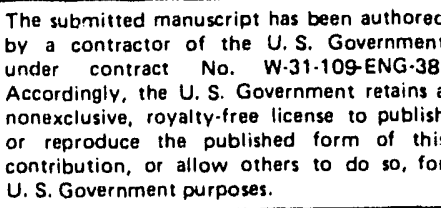




\section{ENERGY AND CRUDE OIL INPUT REQUIREMENTS FOR THE PRODUCTION OF REFORMULATED GASOLINES}

\section{Introduction}

The Clean Air Act Amendments (CAAA) of 1990 require that, beginnirg in 1995, reformulated gasoline (RFG) replace conventional gasoline in the nine worst ozone nonattainment areas in the United States with a 1980 population of 250,000 or more (Section 211(k)). All other ozone nonattainment areas may also require the use of RFG as an element of their states' State Implementation Plans. The CAAA establishes general requirements to be met by RFG (nitrogen oxide emissions and oxygen, benzene, and heavy metals content), as well as a requirement that RFG meet the more stringent of either a formula or performance standard for volatile organic compounds (VOC) and toxic air pollutants. The performance standards are more stringent for 2000 than 1995. The U.S. Environmental Protection Agency (EPA) is responsible for promulgating the regulations implementing the RFG program.

The CAAA state that in developing the RFG regulations, the EPA should require the greatest reductions achievable in ozone-forming VOC and toxic air pollutant emissions, taking into consideration the cost of achieving the emission reductions, any nonair-quality- and other airquality-related health and environmental impacts, and energy requirements (Sec. $211(\mathrm{k})(1)$ ). This paper analyzes the energy and crude oil input requirements associated with the production of various RFGs that would meet the EPA RFG program requirements. Differences in energy and crude oil use among RFGs meeting the same performance standards exist for a number of reasons. In particular, the oxygenates used to provide the required oxygen content for RFGs vary in volume, energy content, volatility, and energy required to produce them. The oxygenates, in turn, affect the volume and composition of the hydrocarbon portion of the RFG.
The specific stimulus for this analysis is the February 1993 EPA Notice of Proposed Rulemaking (NPRM) on RFG, which would allow RFG blended with ethanol to meet a lesser VOC reduction standard (Phase I and II) or a lesser Reid vapor pressure (RVP) standard (Phase I) than RFGs produced with other oxygenates (FR Vol. 58, No. 37). (Phase I RFG is required from 1995 through 1999, and Phase II RFG is required beginning in 2000.) However, the results of the analysis are more generally applicable than to the proposal above. Altemative forms of using ethanol in RFG other than that proposed are considered in this analysis (e.g., ethanol in ethyl tertiary butyl ether [ETBE]). This paper also provides estimates of energy and crude oil requirements associated with RFG with methyl tertiary butyl ether (MTBE), as well as such requirements associated with the production of conventional and oxygenated gasolines for use in the carbon monoxide (CO) control program.

\section{Methodology}

\section{Analysis Framework}

Both feedstock and process energies are estimated in this analysis. For each type of RFG, the volume and type of feedstock (hydrocarbon, alcohol, isobutylene) required for the gasoline and oxygenate components are estimated. The process energies are also estimated by amount and type for refining the hydrocarbons and producing the alcohols, the isobutylene, and the ethers. Together, these process energies and feedstocks define the composite energy requirements of RFG with MTBE, ethanol, and ETBE as oxygenates. The crude oil component of the total energy requirements is specifically identified. The various RFGs are evaluated on the basis of delivering equal energy for constant vehicle miles travelled (VMT). 
The analysis focuses on the production of year 2000 summer (VOC-controlled) RFGs. The RFGs contain $2.1 \%$ oxygen by weight, incorporating a compliance margin to meet the CAAA requirement of $2.0 \%$. The RFGs are produced in a modeled, typical Petroleum Administration Defense District (PADD) II (Chicago area) complex refinery. The Chicago area is one of the nine areas required to use RFG and is a key market for fuel ethanol sales. Although RFG production will vary among PADDs, we believe the direction of the results presented below would be the same in other PADDs.

The refinery-related energy and oil inputs required to produce several gasolines were calculated by Tumer, Mason and Co. (TM) for the National Petroleum Council (NPC) Refining Study, which used the TM refinery linear programming (LP) model (Turner, Mason, and Co. 1993). LP model runs were used to estimate the energy and oil required (1) to produce RFG with MTBE only and (2) to produce a mixed RFG pool, with $70 \%$ of the RFG using MTBE as the oxygenate and $30 \%$ using ethanol. Both of the oxygenates were used at the $2.1 \%$ oxygen content level, consistent with the requirements of the February 1993 EPA NPRM. Both the RFG with MTBE only and the mixed RFG pool were held to the same VOC performance levels $(41 \%$, per the April 1992 version of the EPA's proposed complex model). The total energy content of the total volume of RFG produced daily (i.e., volume $\times$ specific energy content) and other key product characteristics and product volumes (e.g., diesel fuel) were held constant. The refinery model was allowed, within these constraints, to optimize on cost.

Ethanol may be used in RFG in other ways than that proposed by EPA. This analysis examines two such additional uses: all the RFG being produced with ethanol only and with ETBE only. The NPC Refining Study did not include separate runs for either of these RFGs. However, data from the LP model runs just presented and other available LP model runs (which evaluated the energy and oil impacts of changes in the RVP of the hydrocarbon portion of the RFG) were used to approximate the change in the RFG hydrocarbon energy and oil input requirements for these two cases. As with the other RFGs analyzed in this report, these two RFGs comply with EPA's RFG performance standard requirements. The NPC Refining Study also provided an LP model run for conventional gasoline produced in PADD II.

Argonne National Laboratory (ANL) developed a spreadsheet model that incorporates (1) the above computations of energy and oil use in the refinery production of RFG and (2) other estimates of the energy required to produce the various oxygenates outside the refinery. The model also normalizes both sets of estimates to the delivery of equal energy content.

\section{Key Assumptions and Inputs}

The key assumptions and inputs for this analysis include the following:

- The PADD II Complex Refinery Model producing $100 \% \mathrm{RFG}$ is representative of the gasoline refining situation that would exist if the regulations were imposed as proposed.

- The VOC standard for 2000 is such that the refinery must operate at the "knee" in the $\mathrm{VOC} / \mathrm{cost}$ curve, with a costeffectiveness value of about $\$ 10,000$ per summer ton of VOC reduced.

- All marginal changes in isobutylene demand for ether production in merchant ether plants are derived from natural gas liquids.

- Ethanol, methanol, and ether production is as described in the sources referenced below. 


\section{RFG Energy and Crude Oil Requirements}

\section{Volume of RFG Required to Dellver Equal Energy Content}

Four RFGs or RFG product mixes are compared in Table 1: RFG with MTBE, RFG with ETBE, RFG with ethanol, and a mixed RFG pool containing both MTBE and ethanol that would satisfy the recent EPA proposal that (up to) $30 \%$ of the RFG sold in northem nonattainment areas contain ethanol. Also represented is conventional gasoline sold or likely to be sold in PADD II in the absence of regulations requiring RFG; it contains $2 \%$ MTBE.

For each of the gasolines, Table 1 presents (1) the volume of hydrocarbons, ethers, and ethanol in the gasoline needed to achieve the $2.1 \%$ oxygen content ("initial volume") and (2) the energy content of a gallon of the gasoline. These estimates are based on the oxygen content and energy content estimates for the various gasoline components presented in Table 2.

Table 1 also presents, for each gasoline, the volume of gasoline required to deliver the same total energy as is delivered by a gallon of RFG with MTBE at $2.1 \%$ oxygen ("revised volume"). The remaining analysis is based on these revised fuel volumes. RFG with MTBE serves as the baseline for this analysis because it is currently considered the most likely oxygenate. The RFGs are actually very similar in terms of the volume of fuel required to deliver the same energy. As expected, because of the addition of oxygen and the subsequent lower energy content of RFG, a greater volume of RFG is required than is the case with conventional gasoline.

\section{Feedstock Requirements}

The crude oil content of the gasolines varies as shown in Table 1. The estimates of crude oil content take into account the feedstock used to produce these components, but not the process energy requirements.
The hydrocarbon portion of gasoline is assumed to come from $100 \%$ crude oil feedstock. In fact, some natural gas (as hydrogen) and some natural gas liquids (NGLs) are used as feedstocks, and their proportion of the final fuel may vary across gasoline formulations. We have not accounted for this potential shift in feedstock.

The crude oil content of ETBE and MTBE reflects the crude oil feedstock used to produce the isobutylene component of these ethers. Ethanol and methanol have 0\% crude oil content. Isobutylene may be produced from crude oil or NGLs. In this analysis, we assume that all isobutylenes produced outside the refinery and used to make ethers outside the refinery are derived from NGLs. These NGLs are assumed to be derived from natural gas-related sources, not crude oil. We also assume that the isobutylenes used within the refinery to produce ethers are made from crude oil.

The proportion of isobutylene used within the refinery to produce ethers is derived from the NPC Refining Study. For that study, TM developed estimates of the materials that would be used in the refinery in the production of various gasolines, both conventional and reformulated. Table 3 contains TM estimates of the raw materials that would be used in the refinery to produce the MTBE needed for RFG and conventional gasoline production. The listing of MTBE as a "raw material" implies that it (and its isobutylene content) is produced outside the refinery. Where methanol is listed as a "raw material," it is assumed that the isobutylene used with this methanol to produce MTBE is produced in the refinery. Thus, it is straightforward to estimate the proportion of the total MTBE produced within the refinery.

We estimate that, for the case where all the RFG contains MTBE, $7.5 \%$ of the ethers is produced within the refinery. For the RFG with MTBE that is part of the mixed RFG pool containing $30 \%$ RFG with ethanol, the TM estimates suggest that just $2 \%$ of the ether and isobutylene is produced within the refinery. These levels of internal ether production may appear low but are consistent with other process changes within the 
TABLE 1 Energy and Crude Oil Content of 2.1\% RFG

\begin{tabular}{|c|c|c|c|c|c|c|}
\hline Fuel Type & Components & $\begin{array}{l}\text { Initial Volume } \\
\text { (gal) }\end{array}$ & $\begin{array}{c}\text { Energy } \\
\text { Content } \\
\text { of Initial } \\
\text { Volume } \\
(B t u) \\
\end{array}$ & $\begin{array}{l}\text { Revised } \\
\text { Volume to } \\
\text { Deliver Equal } \\
\text { Btu as RFG } \\
\text { with MTBE } \\
\text { Only (gal) }\end{array}$ & $\begin{array}{c}\text { Revised } \\
\text { Energy } \\
\text { Content } \\
\text { of Fuel } \\
\text { (Btu) }\end{array}$ & $\begin{array}{l}\text { Oil Content of } \\
\text { Equal Btu RFG } \\
\text { [Feedstock] } \\
\text { (Btu) }\end{array}$ \\
\hline $\begin{array}{l}\text { RFG with MTBE } \\
\text { at } 2.1 \% \mathrm{O}_{2}\end{array}$ & $\begin{array}{l}\text { HCs } \\
\text { MTBE } \\
\text { Total }\end{array}$ & $\begin{array}{l}0.883 \\
0.117 \\
1.000\end{array}$ & $\begin{array}{r}101,142 \\
10,912 \\
112,053\end{array}$ & $\begin{array}{l}0.883 \\
0.117 \\
1.000\end{array}$ & $\begin{array}{r}101,142 \\
10,912 \\
112,053\end{array}$ & $\begin{array}{r}101,142 \\
647 \\
101,789\end{array}$ \\
\hline $\begin{array}{l}\text { RFG with ETBE } \\
\text { at } 2.1 \% \mathrm{O}_{2}\end{array}$ & $\begin{array}{l}\text { HCs } \\
\text { ETBE } \\
\text { Total }\end{array}$ & $\begin{array}{l}0.867 \\
0.133 \\
1.000\end{array}$ & $\begin{array}{r}99,272 \\
12,891 \\
112,163\end{array}$ & $\begin{array}{l}0.866 \\
0.133 \\
0.999\end{array}$ & $\begin{array}{r}99,175 \\
12,879 \\
112,053\end{array}$ & $\begin{array}{r}99,175 \\
665 \\
99,840\end{array}$ \\
\hline $\begin{array}{l}\text { RFG with } \\
\text { Ethanol at } 2.1 \% \\
\mathrm{O}_{2}\end{array}$ & $\begin{array}{l}\text { HCs } \\
\text { ETOH } \\
\text { Total }\end{array}$ & $\begin{array}{l}0.940 \\
0.060 \\
1.000\end{array}$ & $\begin{array}{r}107,630 \\
4,540 \\
112,170\end{array}$ & $\begin{array}{l}0.939 \\
0.060 \\
0.999\end{array}$ & $\begin{array}{r}107,518 \\
4,535 \\
112,053\end{array}$ & $\begin{array}{r}107,518 \\
0 \\
107,518\end{array}$ \\
\hline $\begin{array}{l}\text { RFG Mix }(70 \% \\
\text { RFG with MTBE } \\
\text { at } 2.1 \% \mathrm{O}_{2} ; 30 \% \\
\text { RFG with ETOH } \\
\left.\text { at } 2.1 \% \mathrm{O}_{2}\right)\end{array}$ & $\begin{array}{l}\text { HCs } \\
\text { MTBE } \\
\text { ETOH } \\
\text { Total }\end{array}$ & $\begin{array}{l}0.900 \\
0.082 \\
0.018 \\
1.000\end{array}$ & $\begin{array}{r}103,088 \\
7,638 \\
1,362 \\
112,088\end{array}$ & $\begin{array}{l}0.900 \\
0.082 \\
0.018 \\
1.000\end{array}$ & $\begin{array}{r}103,056 \\
7,636 \\
1,362 \\
112,053\end{array}$ & $\begin{array}{r}103,056 \\
121 \\
0 \\
103,177\end{array}$ \\
\hline$C G$ in PADD $\|$ & $\begin{array}{l}\text { HCs } \\
\text { MTBE } \\
\text { Total }\end{array}$ & $\begin{array}{l}0.980 \\
0.020 \\
1.000\end{array}$ & $\begin{array}{r}112,210 \\
1,871 \\
114,081\end{array}$ & $\begin{array}{l}0.963 \\
0.020 \\
0.982\end{array}$ & $\begin{array}{r}110,216 \\
1,837 \\
112,053\end{array}$ & $\begin{array}{r}110,216 \\
1,032 \\
111,248\end{array}$ \\
\hline
\end{tabular}

refinery related to production of severely reformulated gasoline. Finally, we estimate that $71 \%$ of the smaller volume of MTBE produced for use with conventional gasoline in PADD II is produced internally.

No separate runs of the RFG made with ETBE were performed. In this analysis, we assume that the crude oil feedstock for isobutylene used in the production of ETBE is the same as that for MTBE only. Because the alcohol content of ETBE and MTBE differ, the crude oil content of the ethers themselves will differ.

The lowest crude oil content of all the fuels delivering equal energy is calculated to be that of RFG with ETBE, and the next-lowest is that of RFG with MTBE only. The mixed RFG pool uses more crude oil feedstock. The RFG with ethanol uses the most crude oil feedstock. All
RFGs, of course, reduce crude oil use compared with that of conventional gasoline.

\section{Process Energy Requirements}

Estimates of the energy and crude oil used to produce the components of the various gasolines were derived from several sources. This section presents these estimates.

\section{Energy and Crude Oil Required to Produce Hydrocarbons}

As indicated above, TM refinery LP model runs determined the energy and materials that would be used in the production of various fuels. Table 3 presents a surnmary of the key results. The estimates were used to determine the energy and oil required to produce the hydrocarbons (HCs) used in the fuels. 
TABLE 2 Oxygen, Alcohol, and Energy Content of Oxygenates and Hydrocarbons

\begin{tabular}{cc}
\hline \multicolumn{1}{c}{ Item } & $\begin{array}{c}\text { Oxygen/ } \\
\text { Alcohol/Energy } \\
\text { Content }\end{array}$ \\
\hline Oxygen Content & \\
in RFG (\%) & \\
$2.1 \% \mathrm{O}_{2}$ & $13.30 \mathrm{ETBE}$ \\
& $11.67 \mathrm{MTBE}$ \\
& 6.00 Ethanol \\
$2.7 \% \mathrm{O}_{2}$ & 17.10 ETBE \\
& $15.00 \mathrm{MTBE}$ \\
& 7.71 Ethanol \\
Alcohol Content & \\
of Ethers (\%) & \\
ETBE & 42.5 \\
MTBE & 33.9 \\
& \\
Energy Content & \\
(Btu/gal) & \\
Ethanol & 75,670 \\
Methanol & 56,560 \\
Isobutylene & 94,000 \\
ETBE & 96,926 \\
MTBE & 93,528 \\
HCs Typical & 114,500 \\
in RFG & \\
Butane & 95,038 \\
\hline
\end{tabular}

For all the runs of RFG and conventional gasoline, it was assumed that all the plant fuel, natural gas, and electricity used in the refinery are used to produce the HCs for motor gasoline, diesel fuels, and jet fuel. These three fuels represent over $75 \%$ of the products of the refinery. The diesel and jet fuel product volumes were held constant between the various RFG and conventional fuel runs and all the runs resulted in the production of an equal amount of gasoline energy for vehicular propulsion, so any differences in the energy and oil required per gallon of $\mathrm{HCs}$ produced were attributed to the different processing requirements of the various RFGs.

Table 4 presents these estimates for the three LP runs indicated in Table 3 . The energy required to produce the HCs used in the mixed RFG pool is greater than for those used in the RFG with MTBE only, because the former HCs need to be more severely processed to achieve the incremental VOC reductions needed to offset the VOC increase from ethanol. Ethanol has a higher blending RVP than MTBE, which, if no other adjustments are made, increases the VOC level of the final fuel. Additional processing of the $\mathrm{HC}$ components is required to achieve a lower RVP level and maintain the same overall VOC level.

Table 4 also presents estimates of the energy required to produce the $\mathrm{HCs}$ used in RFG with ETBE only and RFG with ethanol only. No separate refinery runs were made for these fuels. $100 \%$ production of RFG with ethanol only would require even more severe processing of HCs than that of the HCs in the mixed RFG pool, and additional measures would have to be taken to produce an RFG that maintains the required VOC reduction. Thus, the energy required to produce these $\mathrm{HCs}$ is higher than for the HCs used in other RFGs. Because ETBE has a substantially lower blending RVP than MTBE, refiners could use higher-RVP HCs in the RFG. Use of these higher-RVP HCs should, at a minimum, result in lower plant fuel requirements because less processing of the HCs would be required. Several LP runs of RFG with MTBE and the mixed RFG pool were used to derive estimates of these changes in processing requirements.

\section{Energy and Crude OII Required to Produce MTBE}

Table 5 presents estimates of the energy and crude oil required to produce ethers and ethanol. Estimates of the energy and crude oil required to produce MTBE are largely based on a report by Chem Systems (1992). This report provides estimates of the amount of plant energy required 
TABLE 3 Reflnery Products, Fuels Usage, and MTBE Raw Materlals for PADD II Gasoline: 2000

\begin{tabular}{lrrr}
\hline \multicolumn{1}{c}{ Item } & $\begin{array}{r}\text { Base Case } \\
\text { (No CAAA) }\end{array}$ & $\begin{array}{c}100 \% \text { RFT } \\
\text { (MTBE Only) }\end{array}$ & $\begin{array}{r}100 \% \text { RFG } \\
(30 \% \text { ETOH) }\end{array}$ \\
\hline $\begin{array}{l}\text { Products (Bbl/d) } \\
\text { Gasoline } \\
\text { (\% Ether or Ethanol) }\end{array}$ & $1.682 E+06$ & $1.713 E+06$ & $1.717 E+06$ \\
Diesel & 2 & 12 & 10 \\
Jet Fuel & $6.820 E+05$ & $6.820 E+05$ & $6.820 E+05$ \\
$\quad$ Subtotal & $2.050 E+05$ & $2.050 E+05$ & $2.050 E+05$ \\
Plant Fuel Burned & $3.569 E+06$ & $2.600 E+06$ & $2.604 E+06$ \\
Other & $2.306 E+05$ & $1.855 E+05$ & $2.007 E+05$ \\
Total & $3.620 E+05$ & $3.775 E+05$ & $4.293 E+05$ \\
& $3.162 E+06$ & $3.163 E+06$ & $3.234 E+06$ \\
Fuels Used for Production & & & \\
(Bbl/d FOE $)$ & & & \\
Plant Fuel Burned & $2.306 E+05$ & $1.855 E+05$ & $2.007 E+05$ \\
Natural Gas & $3.290 E+04$ & $6.820 E+04$ & $7.090 E+04$ \\
Purchased & & & \\
Electricity & & & \\
(kWh/d) & $4.021 E+04$ & $3.763 E+04$ & $4.183 E+04$ \\
Total (FOE) & $2.490 E+07$ & $2.330 E+07$ & $2.590 E+07$ \\
& $3.037 E+05$ & $2.913 E+05$ & $3.134 E+05$ \\
Raw Materials for MTBE & & & \\
MTBE & $1.000 E+04$ & $1.840 E+05$ & $1.390 E+05$ \\
Methanol & $8.000 E+03$ & $5.000 E+03$ & $1.000 E+03$ \\
Total MTBE Used & $3.400 E+04$ & $1.990 E+05$ & $1.420 E+05$ \\
\hline
\end{tabular}

a FOE: Fuel Oil Equivalent.

Sources: Turner, Mason, and Co., NPC Refining Study, Table F-3, 1/8/93 draft; Table $Y-1,3 / 30 / 93$ draft; and unpublished information.

for various MTBE production processes. We assume use of the process in which MTBE is produced from field butanes and methanol. Feedstock for the plant energy and feedstock for the butanes and methanol are estimated on the basis of this report and a report on greenhouse gas emissions by DeLuchi (1991).

Several assumptions deserve comment. First, we assume that the Btu ratio of natural gas feedstock to methanol produced is $1.5: 1$. The Chem Systems report suggests a lower ratio, but the one we are using is consistent with the references cited by DeLuchi. Second, all the ether plant energy use is assigned to the production of the ether; we do not account for the fuel gas by-products that are also produced. Third, we assume that the energy required to produce the field butanes and natural gas used in the system is negligible.

As indicated above, some MTBE will be produced within the oil refinery. The final estimates used in the analysis are weighted to 
TABLE 4 Plant Fuel Burned and Other Purchased Fuels to Produce HCs

\begin{tabular}{lcc}
\hline \multicolumn{1}{c}{ Fuels } & $\begin{array}{c}\text { Energy in Plant Fuel } \\
\text { Burned, Natural Gas, and } \\
\text { Electricity to Produce HCs } \\
\text { (Btu/Btu HC Produced) }\end{array}$ & $\begin{array}{c}\text { Energy in Plant Fuel } \\
\text { Burned to Produce HCs } \\
\text { (Btu/Btu HC Produced) }\end{array}$ \\
\hline Base Case & 0.155 & 0.118 \\
RFG with MTBE Only & 0.158 & 0.090 \\
RFG with 70\% MTBE \\
and 30\% ETOH \\
RFG with ETBE Only
\end{tabular}

account for the fact that MTBE plant energy would not be used in their production.

\section{Energy and Crude Oll Required to Produce Ethanol}

The energy requirements for com and ethanol production were derived from a paper by Marland and Turhollow (1991). Their paper provides estimates of the energy and crude oil required to produce ethanol without accounting for by-products of the ethanol production process. However, it also provides estimates of the $\mathrm{CO}_{2}$ emissions associated with ethanol production; these estimates do account for byproducts. Turhollow indicated that the proportion of gross $\mathrm{CO}_{2}$ emissions that their paper assigns to by-products could also be applied to the energy and crude oil use associated with the production of ethanol (Turhollow 1993). We did this, and the results are presented in Table 5.

The Marland and Turhollow estimates are representative of current industry best practice. Ethanol produced to meet incremental RFG demand may be nearer to industry average, and thus more energy-intensive, than indicated here.
TABLE 5 Energy and Crude OII Required to Produce Ethers and Ethanol (outslde the refinery)

\begin{tabular}{lcc}
\hline & \multicolumn{2}{c}{$\begin{array}{c}\text { Btu Required per } \\
\text { Gallon of Oxygenate }\end{array}$} \\
\cline { 2 - 3 } Oxygenate & Energy & Crude Oil \\
\hline MTBE & 17,941 & 0 \\
ETBE & 32,116 & 2,281 \\
Ethanol & 65,517 & 6,292 \\
\hline
\end{tabular}

\section{Energy and Crude Oil Required to Produce ETBE}

We adapted the MTBE production process to develop estimates of the ETBE production process. This may slightly understate ETBE process energy because additional distillation steps are required in ETBE production to achieve the required water removal. The major adaptation is the substitution of the energy required to produce ethanol for that of methanol. 


\section{Energy and Oll Required to Produce RFG}

Table 6 gives the final estimates of the energy and crude oil required to produce the various RFGs and conventional gasoline on the basis of delivering equal energy content. RFG with MTBE only requires the least energy of all RFGs, while RFG with ethanol requires the most. RFG with ETBE requires the least crude oil, while RFG with ethanol again requires the most.

\section{Total Energy and Crude OII Requlrements for RFG at $2.1 \%$ Oxygen Content}

Table 6 also gives the estimates of the total energy required to deliver equal energy for propulsion using year 2000 RFG (at $2.1 \%$ oxygen). If RFG with MTBE is the base fuel, the results presented in this table and Table 7 indicate that the least energy-intensive of the RFG options is RFG with MTBE only. RFG with ETBE and the mixed RFG pool require

TABLE 6 Energy and Crude Oll Required to Produce 2.1\% RFG and Total RFG Energy and Crude Oll Requirements

\begin{tabular}{|c|c|c|c|c|c|}
\hline Fuel Type & Components & $\begin{array}{l}\text { Energy } \\
\text { Required } \\
\text { o Produce } \\
\text { Equal Btu } \\
\text { RFG (Btu) }\end{array}$ & $\begin{array}{l}\text { Oil Required } \\
\text { to Produce } \\
\text { Equal Btu } \\
\text { RFG (Btu) }\end{array}$ & $\begin{array}{l}\text { Total Energy } \\
\text { Required to } \\
\text { Deliver } \\
\text { Equal Btu } \\
\text { RFG (Btu) }\end{array}$ & $\begin{array}{l}\text { Total Oil } \\
\text { Required } \\
\text { to Deliver } \\
\text { Equal Btu } \\
\text { RFG (Btu) }\end{array}$ \\
\hline $\begin{array}{l}\text { RFG with MTBE } \\
\text { at } 2.1 \% \mathrm{O}_{2}\end{array}$ & $\begin{array}{l}\text { HCs } \\
\text { MTBE } \\
\text { Total }\end{array}$ & $\begin{array}{r}15,996 \\
2,037 \\
18,033\end{array}$ & $\begin{array}{r}9,060 \\
0 \\
9,060\end{array}$ & $\begin{array}{r}117,138 \\
12,949 \\
130,087\end{array}$ & $\begin{array}{r}110,202 \\
647 \\
110,849\end{array}$ \\
\hline $\begin{array}{l}\text { RFG with ETBE } \\
\text { at } 2.1 \% \mathrm{O}_{2}\end{array}$ & $\begin{array}{l}\text { HCs } \\
\text { ETBE } \\
\text { Total }\end{array}$ & $\begin{array}{r}15,469 \\
4,203 \\
19,671\end{array}$ & $\begin{array}{r}8,667 \\
303 \\
8,970\end{array}$ & $\begin{array}{r}114,643 \\
17,081 \\
131,725\end{array}$ & $\begin{array}{r}107,842 \\
969 \\
108,811\end{array}$ \\
\hline $\begin{array}{l}\text { RFG with } \\
\text { Ethanol at } 2.1 \% \\
\mathrm{O}_{2}\end{array}$ & $\begin{array}{l}\text { HCs } \\
\text { ETOH } \\
\text { Total }\end{array}$ & $\begin{array}{r}22,314 \\
3,531 \\
25,845\end{array}$ & $\begin{array}{r}13,434 \\
339 \\
13,773\end{array}$ & $\begin{array}{r}129,832 \\
8,067 \\
137,899\end{array}$ & $\begin{array}{r}120,952 \\
339 \\
121,291\end{array}$ \\
\hline $\begin{array}{l}\text { RFG Mix }(70 \% \\
\text { RFG with } \mathrm{MTBE} \\
\text { at } 2.1 \% \mathrm{O}_{2} ; 30 \% \\
\text { RFG with ETOH } \\
\left.\text { at } 2.1 \% \mathrm{O}_{2}\right)\end{array}$ & $\begin{array}{l}\text { HCs } \\
\text { MTBE } \\
\text { ETOH } \\
\text { Total }\end{array}$ & $\begin{array}{r}17,841 \\
1,454 \\
1,060 \\
20,356\end{array}$ & $\begin{array}{r}10,336 \\
0 \\
102 \\
10,438\end{array}$ & $\begin{array}{r}120,897 \\
9,090 \\
2,422 \\
132,409\end{array}$ & $\begin{array}{r}113,392 \\
121 \\
102 \\
113,615\end{array}$ \\
\hline$C G$ in PADD $\|$ & $\begin{array}{l}\text { HCs } \\
\text { MTBE } \\
\text { Total }\end{array}$ & $\begin{array}{r}17,066 \\
263 \\
17,329\end{array}$ & $\begin{array}{r}12,957 \\
0 \\
12,957\end{array}$ & $\begin{array}{r}127,282 \\
2,101 \\
129,382\end{array}$ & $\begin{array}{r}123,173 \\
1,032 \\
124,205\end{array}$ \\
\hline
\end{tabular}


TABLE 7 Relative RFG Energy and Crude Oll Requirements"

\begin{tabular}{lcc}
\hline Fuel Type & $\begin{array}{c}\text { Total Energy Use } \\
\text { vs. RFG with MTBE }\end{array}$ & $\begin{array}{c}\text { Total Crude Oil Use vs. } \\
\text { RFG with MTBE }\end{array}$ \\
\hline RFG with MTBE at 2.1\% O & 1.000 & 1.000 \\
RFG with ETBE at 2.1\% O & 1.013 & 0.982 \\
RFG with ETOH at 2.1\% O & 1.060 & 1.094 \\
RFG mix at 2.1\% $\mathrm{O}_{2}$ & 1.018 & 1.025 \\
CG in PADD ॥ & 0.995 & 1.120 \\
\hline
\end{tabular}

a Based on Table 6.

approximately $1.3-1.8 \%$ more energy. RFG with ethanol requires nearly $6 \%$ more total energy. The least crude oil used to deliver equal energy for propulsion is for RFG with ETBE: $1.8 \%$ less than the base RFG. The mixed RFG pool increases the use of crude oil over the base by $2.5 \%$. RFG with ethanol increases crude oil use by over $9 \%$. All these RFGs require more total energy than conventional gasoline. All use less crude oil than conventional gasoline.

A second mixed RFG pool was evaluated, though it is not shown in the tables. The EPA proposal would allow the ethanol content to be as much as $2.7 \%$ oxygen content by weight. Our analysis indicates that this mixed pool would use $2.0 \%$ more energy ard $2.1 \%$ more crude oil than RFG with MTBE only.

\section{Total Energy and Crude Oll Requirements for Gasolines Used In the CO Control Program}

We used a similar process to develop estimates of the energy and crude oil requirements for gasolines used in the $\mathrm{CO}$ control program. A $2.7 \%$ oxygen content leval is required in $\mathrm{CO}$ nonattainment areas for a portion of the year (typically 4-5 months). Areas requiring the use of RFG year-round will require that the oxygen content level of the RFG be raised during these months (CO control program RFG). Areas not using RFG will simply require $\mathrm{CO}$ control program oxygenated gasoline (OG).

The CO control program RFGs are assumed to differ from the RFGs with $2.1 \%$ oxygen content only in the proportion of oxygenates and HCs in the final fuel. For a given oxygenate, the OGs will use the same volume as the $\mathrm{CO}$ control program RFGs to achieve the $2.7 \%$ oxygen content level. We assume that the energy required to produce the $\mathrm{HCs}$ used in $\mathrm{OG}$ will be the same as that for conventional gasoline.

The results of this analysis indicate that OGs have lower energy requirements than their counterpart CO control program RFGs but use more crude oil. RFG or OG made with ethanol requires greater energy and crude oil use than RFG or OG made with MTBE or ETBE. Ethanol blends currently used (e.g., 10\% ethanol) increase total energy use by $3.2 \%$ and total crude oil use by $5.8 \%$ vs. CO control program RFG with MTBE at $2.7 \%$. As before, all the fuels presented use more total energy but less crude oil than conventional gasoline. 


\section{Conclusions}

Our analysis indicates that RFG requires more energy but less crude oil to produce than conventional gasoline. Using RFG with MTBE as a base and nomalizing the results so that all RFGs deliver equal energy for propulsion, the least energy-intensive of the RFG options is RFG with MTBE only. RFG with ETBE and the mixed RFG pools of MTBE and ethanol (which would fulfill EPA's February 1993 RFG NPRM) require approximately $1.3-2.0 \%$ more energy. RFG with ethanol requires nearly $6 \%$ more total energy.

The least crude oil used to deliver equal energy for propulsion is for RFG with ETBE: $1.8 \%$ less than the base RFG. The RFG product mixes increase the use of crude oil over the base by 2.1-2.5\%. RFG with ethanol alone increases crude oil use by over $9 \%$.

Use of oxygenates at a $2.7 \%$ level in the winter does not alter the direction of these results. Non-reformulated oxygenated gasolines have lower total energy requirements than their corresponding RFGs but use more crude oil.

The specific impetus for this report was the EPA proposal that would allow RFG blended with ethanol to meet a lesser VOC reduction standard than RFGs with other oxygenates. If implemented, the proposal would cause increased energy use of 1.8 to $2.0 \%$, depending on the oxygen level $(2.1$ or $2.7 \%$ ) achieved with the ethanol portion of the mixed RFG pool. Crude oil use would increase by 2.1 to $2.5 \%$.

The results reported here are based on a number of assumptions and are focused on RFGs produced in one area of the country. Changes in assumptions would obviously change the calculated estimates. However, we believe that the general direction of the results is likely to remain the same across regions and with all but drastic changes in production process assumptions.

\section{Acknowledgment}

The authors acknowledge the valuable assistance of Kevin Stork, II.S. Department of Energy intern, and significant data inputs from Bob Cunningham of Turner, Mason \& Co., working for the National Petroleum Council; Oak Ridge National Laboratory; and Chem Systems, Inc. We would also like to thank Mr. Cunningham; Richard Long, Ashland Petroleum Co.; and Robert Warden, Chevron Research and Technology Co., for their review of this analysis. This work was supported in part by the U.S. Department of Energy, Office of Policy, Planning, and Program Evaluation, under contract W-31-109-Eng-38.

\section{References}

Chem Systems, Inc. 1992. "The Global MTBE Business," Appendixes.

DeLuchi, M.A. 1991. Emissions of Greenhouse Gases from the Use of Transportation Fuels and Electricity. Argonne National Laboratory Report ANL/ESD/TM-22.

Marland, G., and A.F. Turhollow. 1991. " $\mathrm{CO}_{2}$ Emission from the Production and Combustion of Fuel Ethanol from Com." Oak Ridge National Laboratory.

Turhollow, A.F. 1993. Personal communication.

Turner, Mason, and Co. 1993. "NPC Refining Study, IIC-Summer 1995/2000 F2-SF and 4/92 CF Case Runs." 

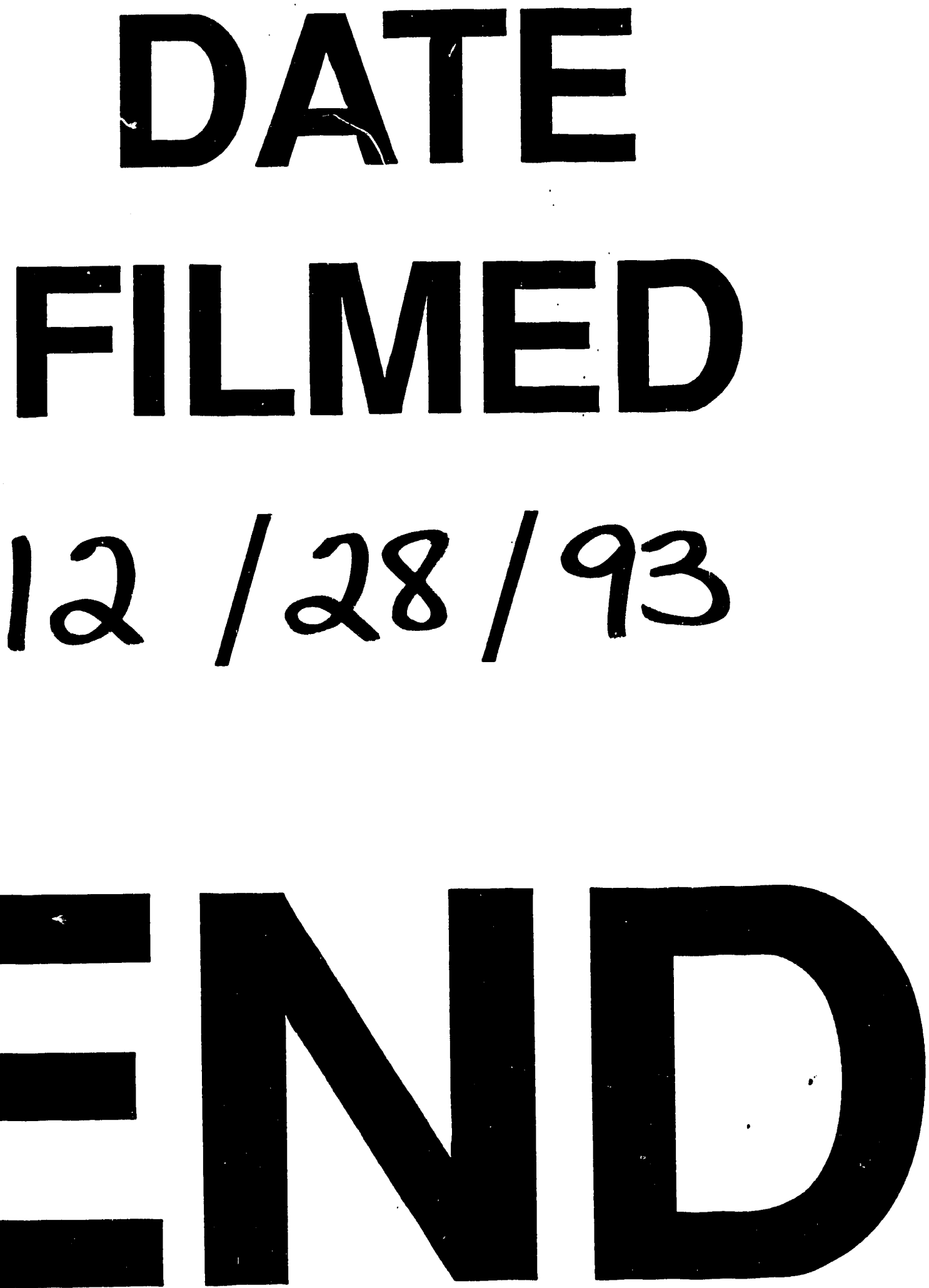
. 